\title{
Specify Other BRAF Mutation
}

National Cancer Institute

\section{Source}

National Cancer Institute. Specify Other BRAF Mutation. NCI Thesaurus. Code C158888.

A request to enter the specific BRAF mutation that was identified in the study but is not present in the form. 